\title{
ISS Stage I Plasma Cell Myeloma
}

National Cancer Institute

\section{Source}

National Cancer Institute. ISS Stage I Plasma Cell Myeloma. NCI Thesaurus. Code C70658.

Plasma cell myeloma with beta-2-microg lobulin less than 3.5 and albumin greater than or equal to 3.5 (median survival of 62 months). Note that the older Durie/Salmon staging system defines stage I quite differently. (PDQ) 